Vol. 10 (4): 661-666 (2020)

\title{
BLUETONGUE VIRUS INFECTION IN CATTLE IN SOME PROVINCES OF NORTH-WEST ALGERIA
}

\author{
Sebai Ali ${ }^{1,2}$, Ghazi Kheira ${ }^{1}$, Meliani Samia ${ }^{3 *}$, Kebir Ahmed ${ }^{2}$, Benyamina Khadra ${ }^{2}$, \\ Bouziri Abdeldjallil ${ }^{2}$ \\ ${ }^{1}$ University of Tiaret, The Veterinary Sciences Institut, 14000, Algeria; \\ ${ }^{2}$ The Regional Veterinary Laboratory of Mostaganem, Algeria; \\ $3^{3 *}$ University of Tiaret, Nature and Life Sciences Faculty, 14000, Algeria; \\ *Corresponding Author Meliani Samia, e-mail: meianisamia@hotmail.com
}

Received August 2020; Accepted September 2020; Published October 2020;

DOI: https://doi.org/10.31407/ijees10.412

\begin{abstract}
The aim of this work was to estimate the sero-prevalence and associated with Culicoides trapping in study area in cattle. BTV sero-positive from seven provinces in north western Algeria, seven provinces were selected. A total 272 animals included three phases of blood collection in season of autumn were randomly collected for detection of BTV group specific antibodies through competitive ELISA (c-ELISA) for assessment of situation epidemiological by prevalence and presence of Culicoides trapping in sites was revealed seropositive. The significant $(\mathrm{p}<0,05)$ highest prevalence of BTV was recorded in province Oran followed by Mostaganem, Relizane, Mascara, Tiaret, Chlef, whereas, the lowest sero-prevalence for BTV was recorded in cattle in province Tissemsilt, presenting $34,37 \%, 19,51 \%, 15,78 \%, 15,55 \%, 13,33 \%, 13,15 \%$ and $6,89 \%$, respectively.
\end{abstract}

Key words: Bluetongue virus, Cattle, Sero-entomology, North-west Algeria. 